\title{
THE EFFECT OF MEDICAL SYMPATHETIC BLOCKAGE (USING RESERPINE) IN THE MANAGEMENT OF SPINAL CORD INJURY IN RATS
}

\author{
By S. M. Rezaian, M.D., F.R.C.S., F.I.C.S., M. Rezvani, Ph.D., M. Movlavi, M.D. \\ and A. DANESHBOD, M.D. \\ Departments of Scoliosis and Surgery of the Spine, and Pharmacology Department, Teheran \\ University, Sina Hospital, Teheran, Iran
}

Abstract. The effect of medical sympathetic blockage with reserpine was studied in 48 rats following crushing of the cord. Control experiments were carried out with reserpined and unreserpined groups. Marked sensory-motor improvement was found in the reserpined group.

Key words: Norepinephrine; dopamine; animal experiments.

\section{Introduction}

FoR many years orthopaedic surgeons have been puzzled with patients who sustain severe cord damage without injury to the bony vertebral column (Schneider \& Crosby, 1959). Such neurological deficit following blunt trauma does not usually result from immediate physical laceration or transection, but rather from delayed inferect cord autodestruction due to arterial insufficiency, accumulation of norepinephrine and dopamine within the wounded tissue (Osterholm et al., 1973; Osterholm \& Mathews, I972). It is assumed that dopamine is a metabolite in transit toward norepinephrine synthesis, as there are no dopamine fibres in the cord. Coincident with peak catecholamine tissue levels, central haemorrhagic necrosis develops. Certain spinal functions should be preserved if such secondary lesions are to be arrested. The purpose of this paper is to report the effect of reserpine used in spinal cord injuries in rats as a medical sympathetic blockage agent.

\section{Material and Method}

Altogether I 5 mature albino rats, of both sexes, weighing from I 80 to $230 \mathrm{~g}$ (average $2 \mathrm{rog}$ ) were used for this work. Forty-seven rats were discarded from the study because they died during anaesthesia or from spinal cord injuries. The procedure was as follows: the whole experimental work was supervised by the orthopaedic surgeon/author (S. M. R.) in double-blind conditions as advised by others (Tator, I965). The rats were divided by our pharmacologist (M. R.) into two groups. In Group I there were 44 rats, each having been treated with $0 \cdot 0$ I reserpine $\mathrm{mg} / \mathrm{g}$ of weight per day for 2 days prior to the spinal injury. Group II consisted of 24 rats, untreated with reserpine, but exposed to similar spinal injury for control. The assistant orthopaedic surgeon (M. M.) was instructed to carry out the operation in ignorance of the group to which the rat belonged. The surviving rats were studied and sacrificed at weekly intervals. The damaged part of the cord was carefully removed and placed in Io per cent formalin solution and sent to the pathologist (A. D.) for histological section; which was carried out without knowledge of the group to which the rat belonged. 


\section{Operation}

Ether general anaesthesia was used. The skin of the dorsum of the rat was surgically prepared. A triangular flap of skin was cut and reflected proximally; the rectus muscles of the spine from $T_{9}$ to $L_{2}$ were reflected laterally. The lamina and transverse process of the $T_{12}$ were exposed. A severe, crushing injury to the spine and cord was produced at this level by gripping the transverse process of $T_{12}$ with a strong Kokher forceps and squeezing hard once. A severe jerk of the hind limbs and tail of the animal was observed at the time of injury. This was followed by paralysis of the hind limbs and urinary and faecal incontinence. Muscles and skin were surgically repaired.

\section{Observation}

In Group I the general condition of the rats was aggravated during reserpine treatment. All of them lost weight-from 30 to $70 \mathrm{~g}$ - prior to spinal injury. They had less tolerance of the anaesthetic than Group II. Of 47 discarded rats, 38 belonged to Group I and only nine to Group II. Rats in Group I made slow but progressive recovery from anaesthesia, whereas those in Group II quickly recovered, followed by general weakness. Rats in Group I recovered from anaesthesia within 24 hours and started to eat and move around, and marked progressive improvement was obvious in subsequent days. Rats in Group II were in a bizarre condition with loss of appetite, and I8 of 24 had faecal and urinary incontinence. All were very dirty, their general condition deteriorated and many of them died. Only I 3 out of 24 survived more than I 5 days. In Group I, 33 out of 44 rats survived for 4 weeks or more. All these 33 remained very clean, indicating that they could control their sphincters after 2 to 3 weeks. Twenty-seven could move their hind limbs and tails and 24 could respond to painful stimuli. Eighteen made almost a full recovery; five of them became pregnant during observation followed by normal births.

\section{Pathology}

All the surviving rats were killed at weekly intervals and the injured spines were studied pathologically in both groups. A marked, crushing injury was noticed equally in both groups post-operatively. By the end of the 2nd week, central necrosis was obvious in the control group, while the treated one showed hardly any necrosis.

\section{Discussion}

The many histological sections established that all the animals had received a crushing cord injury. Clinically and histologically there was undoubtedly a marked difference in recovery of the two groups. It has been argued that the ability of the animals to use their hind limbs may be a result not only of reinnervation of the paralysed muscles, but also partly a result of combined action of static and kinetic reflexes elucidated below the level of crushing and compensatory function of the back muscles which have innervation in segments above the crushing, but they have their anatomical function below the crushing thus forming a connection between the paralysed part of the body and the normal one (Guttmann, 1974).

This may be true for the function of girdle muscles but not the muscles of the 
distal part of the hind limbs. Furthermore, such a compensatory function could not be demonstrated in the control group. We are certain that sympathetic blockage with reserpine provided a better circulation in the crushed area of the cord and probably prevented further damage which has been called autodestruction of the cord (Osterholm et al., I973).

Recently a few such successful experimental studies on the recovery of spinal cord-injured animals have been reported by others. For example, successful treatment of severe experimental spinal cord injuries treated by intracisternal 3- $\alpha$ bimethytyrosein has been reported by Osterholm et al. (1973). Yeo et al. (1975) have noticed a significant improvement in motor power in a group of paraplegic sheep treated with alpha-methyl paratyrosine. Unfortunately, we were unable to duplicate this experiment on the dog because dogs did not tolerate even $\mathrm{I} / 20$ of the dose of reserpine given to the rat.

\section{SUMMARY}

It has been shown that part of the neurological deficit following blunt cord injury may be due to arterial insufficiency and accumulation of norepinephrine and dopamine. Comparative standardised spinal cord injuries were produced in two groups of rats. In Group I, the rats were given $0.01 \mathrm{mg} / \mathrm{IO0} \mathrm{g} / \mathrm{kg}$ weight per day reserpine i.m. 48 hours prior to injury. In Group II the rats were exposed to similar spinal injuries without reserpine treatment for control. Double-blind studies were carried out in both groups. Marked motor and sensory improvement were noticed in the reserpinised group and this was supported histologically. We believe these results are important and may require further research to clarify this complex subject.

\section{RÉSUMÉ}

Il est apparu qu'une partie du déficit neurologique survenant après lésion non pénétrante de la moelle épinière peut être due à une insuffisance artérielle et à l'accumulation de norépinéphrine et dopamine. On a provoqué des lésions comparées et normalisées de la moelle épinière chez deux groupes de rats. Dans le Groupe I, les rats ont reçu 0,0I $\mathrm{mg} / \mathrm{IOO} \mathrm{g} / \mathrm{kg}$ de poids par jour de Réserpine intra-musculaire 48 heures avant la lésion. Dans le Groupe II, les rats ont été exposés à des lésions spinales semblables, sans traitement à la réserpine, pour servir de groupe témoin. Des études sans groupe de contrôle ont été effectuées dans les deux groupes. Des améliorations motrices et sensorielles notables ont été constatées dans le groupe traité à la réserpine et ceci est confirmé par l'histologie. Nous pensons que ces résultats sont importants et peuvent exiger des recherches supplémentaires pour éclaircir ce sujet complexe.

\section{ZUSAMMENFASSUNG}

Es wurde gezeigt, dass in Ratten das neurologische Defizit nach stumpfen Rückenmarksverletzungen könnte die Folge von arterieller Insuffizienz und Vermehrung von Norepinephrine und Dopamine sein. Kontrollbestimmungen wurden an reserpinierten und nicht-reserpinierten Ratten ausgeführt. Erhebliche motorische und sensible Besserung wurde in der reserpinierten Gruppe gefunden, was auch histologisch bestätigt wurden kunnte. Weitere Studien zur Klarifizierung dieses komplexen Probleme sind notwendig.

Acknowledgement. We wish to thank the Director of the Department of Pharmacology and Experimental Medicine, Teheran University, who has provided all facilities for our work. 


\section{REFERENCES}

Allen, A. R. (I9II). Surgery of experimental lesion of spinal cord equivalent to crush injury of fracture dislocation of spinal column. F.A.M.A. 57, 878 .

Anden, N. E., Haggendal, J., Magnusson, T. \& Rosengren, E. (I964). Acta Physiological Scand. 62, I I5; 64, I93.

Ashby, P. et al. (I975). Neurophysiological change following spinal cord lesion in man. Can. F. Neurology Science, 2, $9 \mathrm{I}$.

AssenmaCheR, D. R. \& DuCKER, T. B. (I97I). Experimental traumatic paraplegia. The vascular and pathological change seen in reversible and irreversible spinal cord lesion. F. Bone foint Surg. 53A, 67I.

Bulat, M. (1974). 5 hydroxyindoleacetic acid in lumbar fluid: a specific indicator of spinal. cord injury. $f$. Science, $185,527$.

Guttmann, L. (1973). Spinal Cord Injuries. Blackwell Scientific Publishers, Oxford, London, p. 86.

Osterholm, J. L., HiRTz, D. \& Hill, D. (1973). Successful treatment of severe experimental cord injuries by intracisternal 3 alpha-dimethyl-tyrosin, Surgery Forum, 24, 400.

OSTERHOLM, J. L. \& MATHEwS, G. J. (I972). Altered norepinephrine metabolism, following experimental spinal cord injury in relationship to hemorrhagic necrosis and post wounding neurological deficit. $\mathcal{F}$. Neurosurgery, 36, 386.

SCHNEIDER, R. C. \& CROSBY, E. C. (I959). Vascular insufficiency of brain and spinal cord in spinal trauma. F. Neurology, 9, 643 .

TATLOW, W. F. T. \& BAMMER, H. G. (I957). Sydrome of vertebral artery compression. $\mathcal{F}$. Neurology, 7, 548.

Tator, C. H. (I975). Colling in experimental cord injury. F. Neurosurgery, 42, 739.

Yeo, J. D., PaYne, W., Hinwood, B. \& Kidman, W. (I975). The sequential pathological change in experimental contusion injury of the spinal cord. $\mathcal{F}$. Bone foint Surg., 57B, 253. 